\title{
The influence of groundwater abstraction on interpreting climate controls and extreme recharge events from well hydrographs in semi-arid South Africa
}

\author{
James P. R. Sorensen ${ }^{1,2}$ - Jeff Davies ${ }^{1} \cdot$ Girma Y. Ebrahim $^{3} \cdot$ John Lindle $^{4} \cdot$ Ben P. Marchant ${ }^{1} \cdot$ Matthew J. Ascott $^{1}$. \\ John P. Bloomfield ${ }^{1}$ • Mark O. Cuthbert ${ }^{5,6} \cdot$ Martin Holland $^{7} \cdot$ K. H. Jensen ${ }^{4} \cdot$ M. Shamsudduha ${ }^{8} \cdot$ Karen G. Villholth $^{9}$. \\ Alan M. MacDonald ${ }^{10} \cdot$ Richard G. Taylor $^{2}$
}

Received: 15 December 2020 / Accepted: 28 July 2021 / Published online: 21 September 2021

(C) The Author(s) 2021

\begin{abstract}
There is a scarcity of long-term groundwater hydrographs from sub-Saharan Africa to investigate groundwater sustainability, processes and controls. This paper presents an analysis of 21 hydrographs from semi-arid South Africa. Hydrographs from 1980 to 2000 were converted to standardised groundwater level indices and rationalised into four types (C1-C4) using hierarchical cluster analysis. Mean hydrographs for each type were cross-correlated with standardised precipitation and streamflow indices. Relationships with the El NiñoSouthern Oscillation (ENSO) were also investigated. The four hydrograph types show a transition of autocorrelation over increasing timescales and increasingly subdued responses to rainfall. Type $\mathrm{C} 1$ strongly relates to rainfall, responding in most years, whereas $\mathrm{C} 4$ notably responds to only a single extreme event in 2000 and has limited relationship with rainfall. Types C2, C3 and C4 have stronger statistical relationships with standardised streamflow than standardised rainfall. $\mathrm{C} 3$ and $\mathrm{C} 4$ changes are significantly $(p<0.05)$ correlated to the mean wet season ENSO anomaly, indicating a tendency for substantial or minimal recharge to occur during extreme negative and positive ENSO years, respectively. The range of different hydrograph types, sometimes within only a few kilometres of each other, appears to be a result of abstraction interference and cannot be confidently attributed to variations in climate or hydrogeological setting. It is possible that high groundwater abstraction near $\mathrm{C} 3 / \mathrm{C} 4$ sites masks frequent small-scale recharge events observed at $\mathrm{C} 1 / \mathrm{C} 2$ sites, resulting in extreme events associated with negative ENSO years being more visible in the time series.
\end{abstract}

Keywords Groundwater recharge $\cdot$ Teleconnections $\cdot$ Abstraction $\cdot$ Semi-arid $\cdot$ South Africa

\section{Introduction}

Water use in Africa is forecast to dramatically increase (Wada and Bierkens 2014), as more than half of global population growth by 2050 is projected to occur within the sub-Saharan

James P. R. Sorensen

jare1@bgs.ac.uk

1 British Geological Survey, Maclean Building, Wallingford OX10 8BB, UK

2 Department of Geography, University College London, London WC1E 6BT, UK

3 International Water Management Institute, P.O. Box 5689, Addis Ababa, Ethiopia

4 Department of Geosciences and Natural Resource Management, University of Copenhagen, Copenhagen, Denmark region (UN 2019). Demand will be enhanced by increases in drinking water consumption, industry (Nieuwoudt et al. 2004), and irrigation for food production (Altchenko and Villholth 2015) in a continent where only 5\% of arable land is currently irrigated (Siebert et al. 2010).

5 School of Earth and Environmental Sciences, Cardiff University, Cardiff, UK

6 School of Civil and Environmental Engineering, The University of New South Wales (UNSW), Sydney, Australia

7 Delta-H Water Systems Modelling PTY Ltd, Faerie Glen, Pretoria, South Africa

8 Department of Geography, University of Sussex, Brighton, UK

9 International Water Management Institute, Cresswell Road, Pretoria, South Africa

10 British Geological Survey, Lyell Centre, Edinburgh EH14 4AP, UK 
Groundwater is the largest store of freshwater in sub-Saharan Africa (MacDonald et al. 2012) and offers unrealised potential to contribute to meeting future water demands (Cobbing and Hiller 2019). Additionally, the exploitation of groundwater resources offers a myriad of benefits over surface water alternatives, particularly in this region of pronounced climatic variability (Braune and Xu 2010; Gaye and Tindimugaya 2019) of which $40 \%$ is classified as drylands (Cobbing and Hiller 2019).

Long-term groundwater hydrographs provide a direct indicator of groundwater abstraction sustainability from a quantitative perspective: allowing assessments of changes in storage, understanding recharge, and linkages to climate and land use change (Cuthbert et al. 2019). The rarity of such hydrographs has meant assessments of sub-Saharan African water security typically rely on datasets derived from large-scale models (e.g. Döll and Fiedler 2008), with limited validation using field observations (Sood and Smakhtin 2015), or large-scale data reviews (MacDonald et al. 2021). There are examples in the literature of multidecadal African hydrographs which have been used to estimate groundwater recharge and its association with rainfall intensity and climate variability (Kotchoni et al. 2019; Owor et al. 2009; Sibanda et al. 2009; Taylor et al. 2013); or changes in storage relating to land use changes (Favreau et al. 2009), abstraction and managed aquifer recharge (Murray et al. 2018). However, these studies have only examined hydrograph variation at a limited number of locations: from a single wellfield (Taylor et al. 2013) to a limited number of sites spread across an entire country (Kotchoni et al. 2019).

Broader studies include Cuthbert et al. (2019) who suggested three types of annual rainfall-recharge relationship relating to climatic zones from analysis of 14 multi-decadal hydrographs in nine countries across sub-Saharan Africa. Type 1 hydrographs were only present in humid and sub-humid climates where recharge was perennially consistent and uncorrelated to annual rainfall. Type 2 hydrographs showed increasing annual recharge with annual precipitation above governing precipitation thresholds, which tend to be greater as aridity increases, and occur across several climatic zones. Type 3 hydrographs occur in semi-arid to hyper-arid zones and have complex precipitation-recharge relationships, with recharge often only occurring in response to extreme precipitation events. In addition, Ascott et al. (2020) analysed 12 multi-decadal hydrographs from the Burkina Faso national monitoring network and distinguished them into sites showing: (1) long-term decline, (2) intra-annual variability, and (3) multi-decadal variability.

This paper presents an analysis of 21 long-term groundwater hydrographs from two adjacent semi-arid catchments in Limpopo Province, South Africa. This dataset is rare in the context of the previously mentioned studies as it allows us to investigate a larger number of long-term hydrographs distributed across a smaller area $\left(35,100 \mathrm{~km}^{2}\right)$ where climate variation is more limited. The area includes crystalline rock aquifers, which are widespread across the continent (Wright 1992). Furthermore, groundwater use is already extensively utilised here, with well-developed irrigated agriculture comprising an estimated 23\% of cropped land in the Province (Cai et al. 2017). The paper aims to: (1) rationalise hydrograph behaviour into distinct types; (2) understand why these types exist spatially in the context of climate, hydrogeology, and land use and abstraction; (3) explore how these types relate to the recharge drivers of streamflow and climate, including the El Niño-Southern Oscillation (ENSO).

\section{Methods}

\section{Study area}

The study area comprises the Mogalakwena $\left(19,200 \mathrm{~km}^{2}\right)$ and Sand River $\left(15,900 \mathrm{~km}^{2}\right)$ catchments south of the east-west trending Soutpansberg mountain range within the Limpopo River Basin, Limpopo Province, northern South Africa (Fig. 1a,b). This semi-arid area is characterised by mean annual precipitation of 458 and $634 \mathrm{~mm}$ at Mara and Bela-Bela meteorological stations (1965-2010, Fig. S1 of the electronic supplementary material (ESM)-respectively, which is much lower than mean annual potential evaporation of $1,456 \mathrm{~mm}$ (DWS 2015). Rainfall falls predominantly (93\%) in the summer wet season between October, the start of the hydrological year, and April (Fig. 1c). The main river channels in the catchments are usually perennial, but flows are limited in the dry season, being absent during periods of drought (see Fig. S2 of the ESM for monthly flows in the Mogalakwena River from 1965 to 2008). Most tributaries are ephemeral, flowing during the wet season or in response to event-driven intense rainfall (Holland and Witthüser 2011). Streamflow is primarily a result of recent rainfall, with baseflow a minor component as evidenced by limited or absent dry season flow. Elevation ranges between approximately 700 and 2,100 $\mathrm{m}$ above sea level.

Annual rainfall is highly variable (coefficient of variation 25-35\%, Fig. S1 of the ESM), with a consequential cycle of droughts and floods (Wetterhall et al. 2015). ENSO is considered the main cause of interannual variability in rainfall in southern Africa (Kolusu et al. 2019). Positive ENSO events (El Niño) and negative ENSO events (La Niña) have been associated with below-average and above-average summer rainfall, respectively, in South Africa (MacKellar et al. 2014; Reason et al. 2005). Nevertheless, any relationship between ENSO and rainfall is nonlinear and complicated by interactions with other modes of atmospheric variability (Fauchereau et al. 2009) such as the Indian Ocean Dipole (Gaughan et al. 2016). 


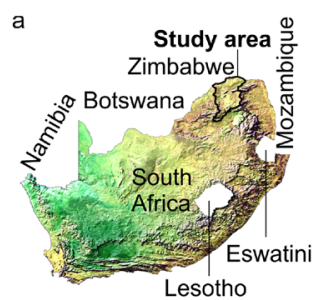

C

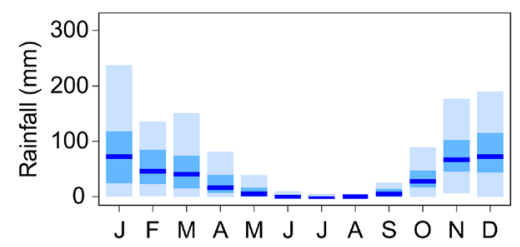

b

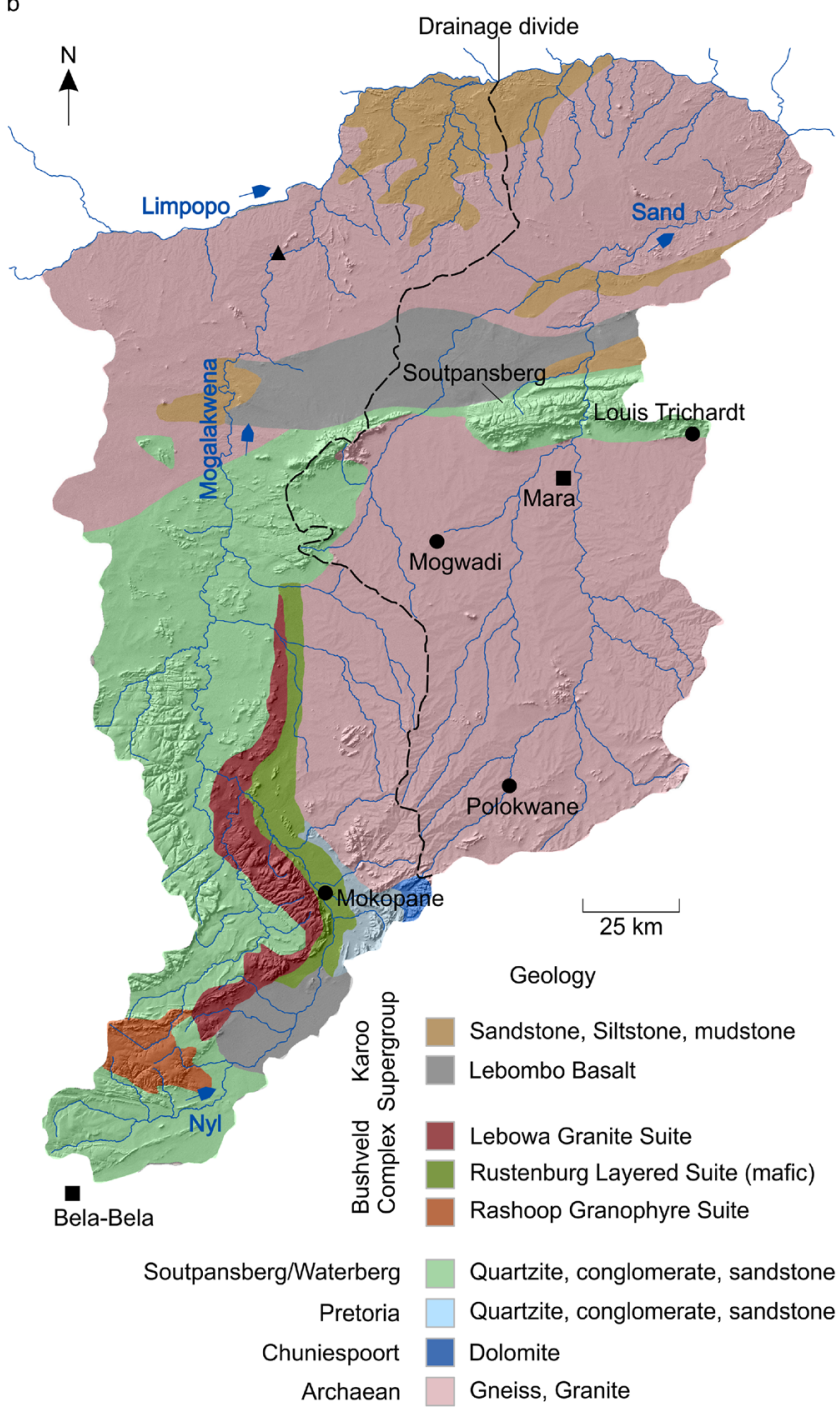

Fig. 1 a Location of study area within South Africa; $\mathbf{b}$ Detailed study area map illustrating geology, urban centres (black circles), South African Weather Service meteorological stations (black squares), river gauge (black triangle), and surface water flow direction (blue arrows). Bedrock geology simplified from the 1:1000000 map of South Africa (Council for Geoscience 2019); c Boxplot of monthly rainfall at Mara (1965-2010) showing median (dark blue), interquartile range (IQR) (blue), calculated minima and maxima (1.5 $\times$ IQR) (light blue), and outliers excluded

The geology of the catchments is dominated by: crystalline basement rocks (gneiss/granite); the Northern Limb of the Bushveld Complex; the Soutpansberg and Waterberg Group; and the Karoo Supergroup. Basement rocks are of Archaean age and mainly comprise granite and gneiss. The Bushveld Complex intruded into the basement approximately 2 billion years ago and includes the Lebowa Granites and the mainly gabbroic succession of the Rustenburg Layered Suite. These crystalline rocks are all overlain by a regolith of between 10 and $50 \mathrm{~m}$ thick (Holland 2011). The Proterozoic Soutpansberg and Waterberg Group include red quartzitic sandstones and conglomerates with basaltic lavas forming the $\mathrm{E}-\mathrm{W}$ trending Soutpansberg. The Karoo Supergroup consists of a mixture of sandstone, siltstones, and mudstones, as well as the Lebombo Basalt. There are frequent ENE-NE trending dyke swarms evident in aeromagnetic data (Stettler et al. 1989).

Younger alluvial deposits are found along the main river channels. Localised investigations have demonstrated 4-16 m of clay and sand at the Polokwane sewage works, and 10$14 \mathrm{~m}$ of red or sandy clay overlying $4-10 \mathrm{~m}$ of sand, gravel and pebbles at Mara within the Sand River Catchment (Vegter 2003). These deposits comprise local aquifers that are completely saturated beneath the rivers during streamflow. On the floodplain of the Nyl River, around $35 \mathrm{~m}$ of sediments have accumulated in the Nylsvlei wetland upstream of the confluence with the Mogalakwena River (McCarthy et al. 2011).

Mean transmissivity and mean borehole yields are similar between dominant lithology types in Limpopo Province with variations of $20-44 \mathrm{~m}^{2} /$ day and $0.7-1.3 \mathrm{~L} / \mathrm{s}$, respectively (Holland 2011; Holland and Witthüser 2011). Basement aquifers are slightly higher yielding than elsewhere in southern Africa and there are localised high yield anomalies, notably air lift yields of $40 \mathrm{~L} / \mathrm{s}$ are common around Mogwadi (Holland 2011). Water storage and movement is via the matrix and fractures in the weathered basement and Bushveld Complex; fractures in the Soutpansberge/Waterberg and Karoo; and only the matrix in the alluvium (du Toit 2003). Runoff is generally low due to the low topographic gradient and sandy soils (DWS 2015).

There has been intensive investment in pivot irrigation (Cai et al. 2017; Ebrahim et al. 2019), and it is estimated that irrigation for the commercial agricultural sector constitutes around $80 \%$ of water withdrawals in both catchments, which is almost exclusively supplied by groundwater (DWAF 2004). The town of Mogwadi and many rural communities are completely groundwater dependent; wellfields also partially supply Polokwane and Mokopane, in addition to some mining operations (DWAF 2004; DWS 2015).

\section{Data and study period selection}

Within the study catchments there are at least 21 monitoring boreholes with long-term records ( $>20$ years) monitored by the Department of Water and Sanitation (DWS); the longest 
record extends from 1965 until 2013. Retrieved DWS data were converted to mean monthly time series from a mix of monthly dipped and hourly logged observations. Linear interpolation was then used to infill any gaps equal to or less than 3 months, given the long hydraulic memory typically observed within aquifers in drylands (Opie et al. 2020). Outstanding gaps were infilled using the hydrograph with the highest correlation coefficient, where overlapping data were available. The first derivative of the correlated hydrograph was used to infill because of discrepancies in the absolute values between sites. All infilling was visually inspected to confirm anomalous data were not introduced. Finally, a 20-year study period was selected where all records were complete following infilling: between November 1980 and November 2000 (Fig. 2). The entire dataset during this period was $94 \%$ original, $4 \%$ infilled by linear interpolation, and $2 \%$ infilled using a correlated hydrograph. There are limited supporting data available for the boreholes: depths are unknown, there are no lithological logs or completion details, site specific aquifer properties are unclear with an absence of pumping test data, and the authors are not aware of any attempts to characterise fractures.

Long-term daily rainfall data were retrieved from South African Weather Service (SAWS) climate stations at Mara (1949-present, $900 \mathrm{~m}$ above mean sea level (m asl)) and the more elevated Bela-Bela (1937-present, $1130 \mathrm{~m}$ asl). No infilling of data was conducted over the study period and any missing data were assumed to be zero. The Bela-Bela record contains 34 daily gaps, 33 of which occurred during the dry season; no rainfall on the single missing wet season

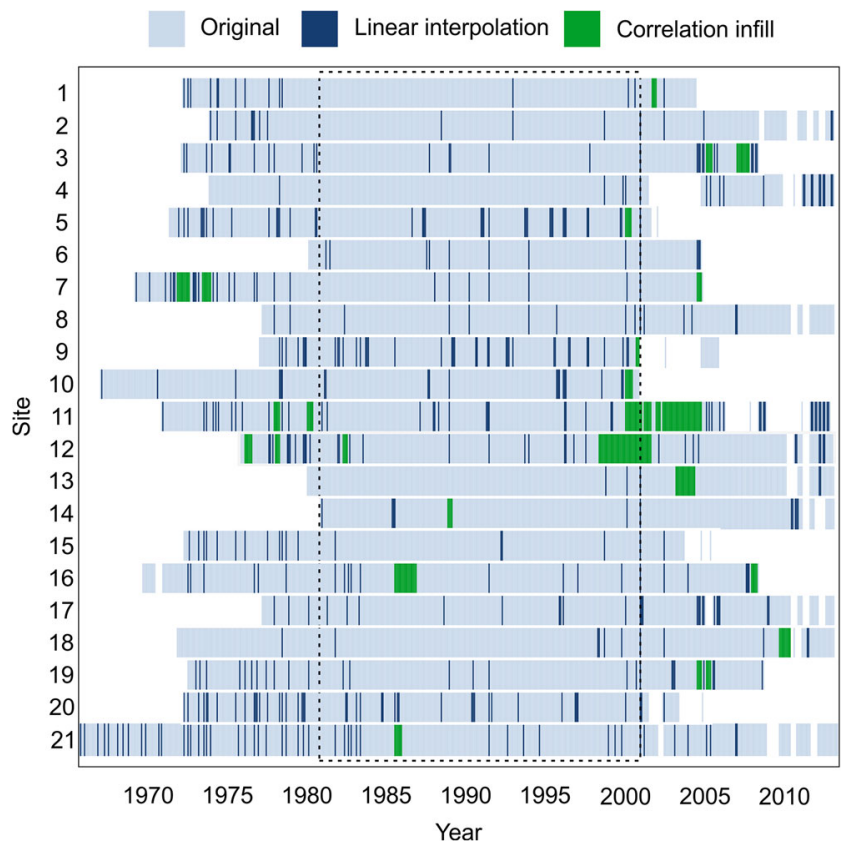

Fig. 2 Borehole hydrograph data availability and infilling. Dotted line illustrates the selected study period. Respective DWS names and metadata for the sites are provided in Table 1 day occurred at Mara. The Mara record includes 37 gaps, of which 32 days were in the dry season. The corresponding Bela-Bela data over the five missing wet season days were $0,0,1,4.8$, and $33 \mathrm{~mm}$. Rainfall at both stations were summed to monthly data.

Monthly river flow data were retrieved from DWS for the Mogalakwena gauge (A6H009) aggregating across an area of $14,700 \mathrm{~km}^{2}$, almost the entire catchment, with data spanning from 1960 to 2008. During the study period, there were four gaps: three of which occurred towards the end of the dry season in either August or September, when flows are generally low or absent, and one during the drought of 1992, in February, when rainfall was only $24 \mathrm{~mm}$ at Mara (Fig. S2 of the ESM). These four gaps were filled by linear interpolation. There were no suitable river flow data covering the study period available for the Sand River Catchment.

The study period commences following successive years of consistently above mean rainfall (Fig. S1 of the ESM) - for example, between 1972 and 1980 at Mara, annual rainfall ranged between 513 and $734 \mathrm{~mm}$, with a mean of $610 \mathrm{~mm}$, $>30 \%$ above the longer term mean. The study period includes major regional droughts including 1982 and 1992 (Trambauer et al. 2014). Exceptional rainfall also triggered major flood events in both 1996 and 2000 (Crimp and Mason 1999; Dyson and Van Heerden 2001). The 2000 event was the most extreme-for example, $1,388 \mathrm{~mm}$ of rainfall fell in Louis Trichardt during February 2000 (Dyson and Van Heerden 2001).

Supporting high spatial resolution (30 s of a longitude/ latitude degree) distributed datasets of annual mean rainfall (1970-2000; Fick and Hijmans 2017) and aridity index (Trabucco and Zomer 2018) were retrieved. These climatological datasets were mapped across the study area and individual values extracted for each borehole (Table 1) to supplement the data from the two meteorological stations. Land use data were retrieved from the South African Department of Agriculture, Forestry and Fisheries (DAFF 2015). These data were simplified for visualisation into eight categories: natural vegetation, commercial agriculture (including pivot irrigation), commercial agriculture (irrigated without the use of pivots), subsistence agriculture, mining, town/village, open water, and wetland. All agricultural categories are classified into low, medium, or high intensity in the source data. The Multivariate ENSO Index Version 2 (MEI) (NOAA 2020) was used to investigate the teleconnection between groundwater levels and ENSO.

\section{Normalising hydrological data}

To compare hydrographs across the study area, hydrographs were normalised to the standardised groundwater level index (SGI) following Bloomfield and Marchant (2013) for the study period. SGI is a 
nonparametric normalisation: data from a site are split into observations from each calendar month; data within each month are ordered, assigned a rank, and an inverse normal cumulative distribution function is applied; finally, the normalised monthly indices are merged to form a continuous SGI time series (Bloomfield et al. 2015). An SGI time series has a mean of zero and a standard deviation of 1 . Note that this process inherently removes seasonality from the hydrographs.

Precipitation and river flow data were normalised following the same approach as the SGI, for consistency, and form a version of the standardised precipitation index (SPI; McKee et al. 1993) and standardised streamflow index (SSI; Vicente-Serrano et al. 2012), respectively. This process was undertaken for accumulation periods (aggregated rainfall) of $k=1-36$ months to create $\mathrm{SPI}_{1-36}$ and $\mathrm{SSI}_{1-36}$. Note that as the accumulation period increases, month-to-month time-series variability is smoothed.

\section{Statistical analysis}

Cluster analysis was used to explore similarity between SGI time series and provide rationalisation of hydrographs into specific types. There are a wide range of clustering algorithms available (Haaf and Barthel 2018), which can be broadly split into hierarchical and non-hierarchical, although the decision over the approach to pursue is rather subjective (Webster and Oliver 1990). The hierarchical hclust function in $\mathrm{R}$ was selected for this study; utilising the minimum error sum of squares algorithm of Ward (1963). Initially each time series is allotted to its own cluster, before the algorithm proceeds iteratively joining the two most similar clusters, until a single cluster is formed. At each iteration, distances between clusters are recalculated by the Lance-Williams dissimilarity update formula applied according to Ward's approach.

The autocorrelation of a time series demonstrates its correlation to a delayed copy of itself as a function of the delay, which was determined for each SGI time series using the Acf function in R. The autocorrelation of a hydrograph is representative of the hydrological memory in the system and was used to define the optimal number of clusters. Four clusters captured the main types of autocorrelation structure, with further clusters being single sites. A mean hydrograph $(\mathrm{MH})$ of all SGI hydrographs within each cluster was produced to rationalise hydrological responses for further investigation.

SGI MHs were cross-correlated with both SPIs and SSI across accumulation periods of 1-36 months and lags of 0 6 months to examine differences in hydrological drivers

Table 1 Metadata for each site

Site DWS ID Latitude $\left({ }^{\circ}\right.$ ) Longitude $\left({ }^{\circ}\right.$ ) Elevation (m asl) Data commence Date cease Mean GWL (m bd) Aridity index Annual rainfall $(\mathrm{mm})$

\begin{tabular}{|c|c|c|c|c|c|c|c|c|c|}
\hline 1 & A7N0509 & -23.9181 & 29.4436 & 1,290 & $13 / 03 / 1972$ & $15 / 06 / 2004$ & -18.36 & 0.32 & 609 \\
\hline 2 & A7N0539 & -23.9083 & 29.4481 & 1,260 & $13 / 11 / 1973$ & - & -14.37 & 0.35 & 650 \\
\hline 3 & B5N0031 & -24.3842 & 29.0111 & 1,080 & $15 / 02 / 1972$ & $14 / 05 / 2008$ & -10.22 & 0.26 & 538 \\
\hline 4 & A7N0561 & -23.9011 & 29.4278 & 1,240 & $12 / 11 / 1973$ & - & -7.26 & 0.31 & 589 \\
\hline 5 & A6N0031 & -24.4422 & 28.9119 & 1,070 & $10 / 05 / 1971$ & $23 / 01 / 2002$ & -14.80 & 0.27 & 542 \\
\hline 6 & A6N0078 & -24.1506 & 29.1461 & 1,340 & 09/01/1980 & $18 / 10 / 2004$ & -12.29 & 0.33 & 627 \\
\hline 7 & A6N0019 & -24.1475 & 29.1692 & 1,400 & $18 / 03 / 1969$ & $10 / 11 / 2004$ & -15.84 & 0.35 & 654 \\
\hline 8 & A6N0069 & -24.1725 & 29.1744 & 1,450 & 08/03/1977 & - & -41.98 & 0.37 & 675 \\
\hline 9 & A7N0580 & -23.9742 & 29.5919 & 1,330 & 06/01/1977 & $08 / 11 / 2005$ & -1.46 & 0.38 & 718 \\
\hline 10 & A6N0017 & -24.5672 & 28.7667 & 1,080 & $12 / 01 / 1967$ & $02 / 11 / 2000$ & -14.39 & 0.27 & 554 \\
\hline 11 & A6N0023 & -24.5533 & 28.7508 & 1,070 & $24 / 11 / 1997$ & $13 / 11 / 2012$ & -8.76 & 0.27 & 552 \\
\hline 12 & A6N0059 & -24.3486 & 28.9386 & 1,060 & $29 / 09 / 1975$ & - & -11.09 & 0.26 & 529 \\
\hline 13 & A6N0079 & -24.1989 & 28.9678 & 1,060 & $10 / 01 / 1980$ & - & -7.34 & 0.27 & 535 \\
\hline 14 & A6N0044 & -24.1744 & 29.0097 & 1,120 & 03/11/1980 & - & -12.24 & 0.28 & 566 \\
\hline 15 & A7N0511 & -23.9344 & 29.4653 & 1,280 & $13 / 03 / 1972$ & $13 / 05 / 2005$ & -10.62 & 0.33 & 620 \\
\hline 16 & A7N0556 & -23.6731 & 29.5956 & 1,110 & $15 / 09 / 1969$ & $15 / 05 / 2008$ & -12.78 & 0.35 & 668 \\
\hline 17 & A6N0534 & -24.1217 & 28.9172 & 1,040 & 02/03/1977 & - & -11.88 & 0.26 & 520 \\
\hline 18 & A7N0549 & -23.9075 & 29.4125 & 1,250 & 05/11/1971 & - & -9.10 & 0.30 & 585 \\
\hline 19 & A6N0505 & -23.6481 & 28.8725 & 1,010 & $14 / 07 / 1972$ & 04/09/2008 & -23.78 & 0.24 & 502 \\
\hline 20 & A7N0513 & -23.9381 & 29.4783 & 1,300 & $13 / 03 / 1972$ & $14 / 05 / 2003$ & -18.69 & 0.34 & 641 \\
\hline 21 & A7N0524 & -23.3625 & 29.2744 & 1,040 & $10 / 09 / 1965$ & - & -29.89 & 0.28 & 554 \\
\hline
\end{tabular}

Note: within the DWS ID field, A6 and A7 refer to the Mogalakwena and Sand River Catchments, respectively 
between cluster types (Barker et al. 2016; Bloomfield and Marchant 2013). To investigate the relationship between ENSO anomalies - represented by MEI.v2 (MEI) - and SGIs, the MEI was averaged over October to April for each hydrological year and correlated by Spearman's rank-order correlation with the change in SGI over the same period. All statistical analyses were performed in $\mathrm{R}$ version 3.4.0 ( $\mathrm{R}$ Core Team 2017).

\section{Results}

\section{Hydrograph classification}

The SGI hydrographs were grouped into four distinct clusters (C1-C4; Fig. 3a,b), which each display a unique autocorrelation structure (Fig. 3c). The clusters are numbered sequentially according to the maximum length of their significant mean positive autocorrelation: $\mathrm{C} 1$ (28 months), C2 (36 months), C3 (56 months), C4 (70 months). Increasing the number of clusters beyond four produces clusters containing only single sites - for example, cluster 5 is BH 9 and cluster 6 is BH 5. These two sites do have a similar autocorrelation structure to the $\mathrm{C} 2$ mean, but they are the two sites with autocorrelation furthest from any of the four cluster means (Fig. 3c).

Different cluster mean hydrographs (MHs) have characteristic responses to precipitation and length of recessions (Figs. $3 \mathrm{~b}$ and 4 ). These observations explain the autocorrelation: increasing autocorrelation is associated with increasingly subdued responses to rainfall and longer periods of groundwater recession. MH C1 fluctuates through multiple periods of above and below normal SGI between 1980 and 1991 before retreating to its lowest levels between 1992 and 1995. During 1996, the SGI rises rapidly and remains above normal through to 2000 where SGIs increase to their maximum. MH C2 interannual fluctuations are similar but more limited than $\mathrm{MH}$ C1 between 1980 and 1996, with the time series in recession except during 1987 and 1991. During 1996, the SGI rises rapidly before recessing below normal in 1998 and increasing again in 2000. MH C3 is in recession in nearly all years with the notable exceptions of the extreme rainfall events of 1996 and 2000 occurring during negative ENSO periods (Fig. 4b,c). MH C4 is also in recession in nearly all years, with the only notable exception of 2000 when both SPI and SSI were most positive (Fig. 4c). Both $\mathrm{C} 3$ and $\mathrm{C} 4 \mathrm{MHs}$ are at their maxima at the beginning of the study period.

There is broad consistency of SGI time series within each cluster and with its respective MH (Fig. 4a). The most divergent time series within a cluster are $\mathrm{BH} 5$ and $\mathrm{BH} 9$ within $\mathrm{C} 2$, as previously distinguished by their autocorrelation (Fig. 3a, c). These sites have periods of below normal SGI pre-1988 when other time series are at least normal; do not have the same coherent negative SGI in 1992-1995; and are more

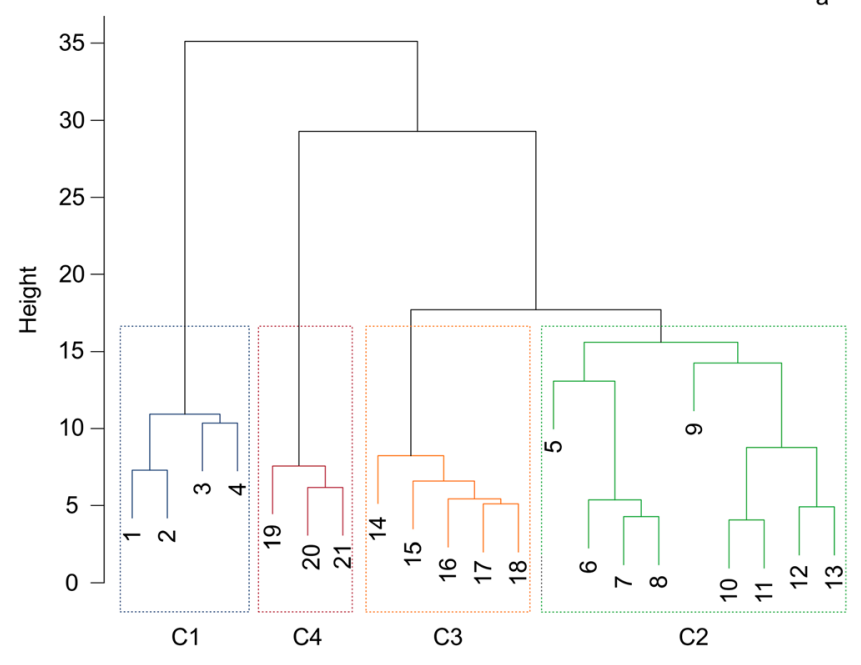

b

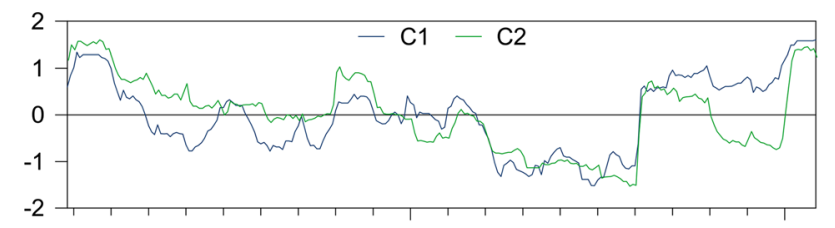

(5)
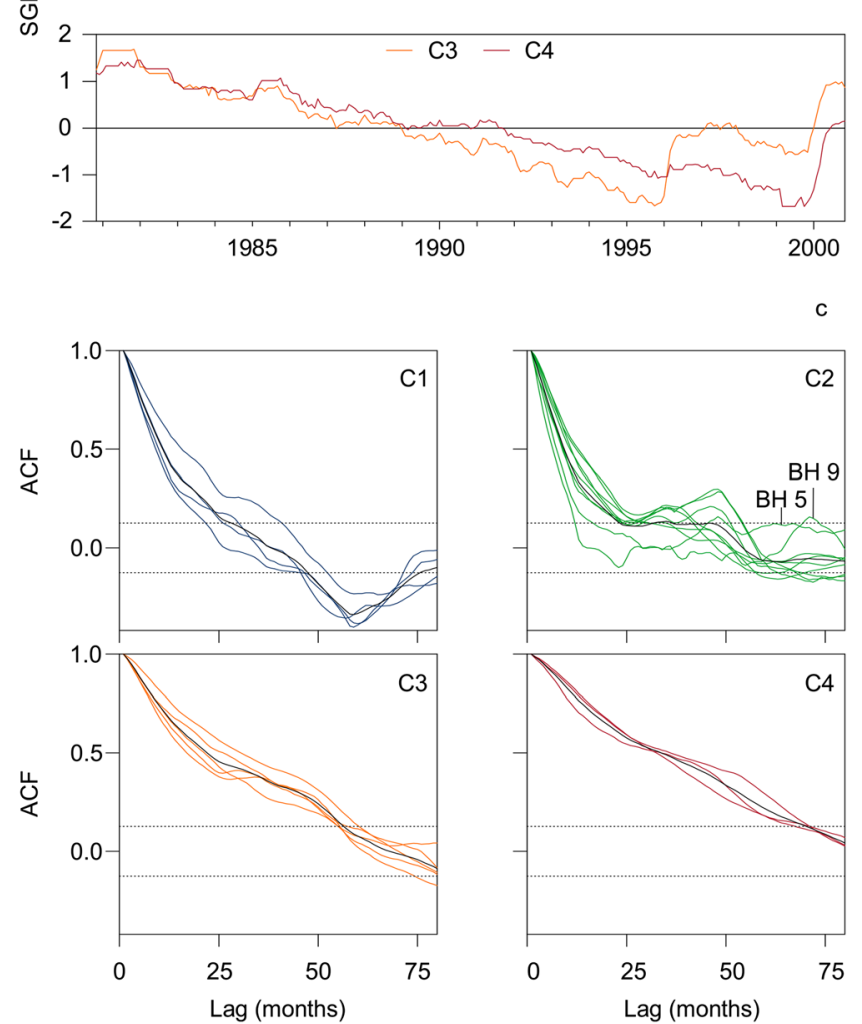

Fig. 3 a Hierarchical cluster dendrogram separated into four clusters (C1-C4); b Mean SGI hydrograph for each cluster; c correlograms for each SGI time series split by hierarchical cluster for lags up to 80 months. The mean correlogram for each cluster is shown in black and the horizontal dotted lines denotes significance $(p<0.05)$

negative in 1998-1999. Interestingly, BH 20 is the only site in C4 that responds to the 1996 rainfall event (Fig. 4a). 


\section{Spatial distribution of cluster types}

In the Mogalakwena catchment, there appears a transition from predominantly $\mathrm{C} 2$ sites and a single $\mathrm{C} 1$ site, to $\mathrm{C} 3$ sites, and then $\mathrm{C} 4$ sites downstream in the catchment (Fig. 5). The transition to $\mathrm{C} 3$ sites occurs abruptly at Mokopane, for example site 13 (C2, upstream of town) is within $5 \mathrm{~km}$ of site 14 (C3, within the town). In the Sand River catchment, there is a similar transition downstream along the catchment from site 9 (C2), to site 16 (C3) and finally, site 21 (C4). However, around Polokwane, $\mathrm{C} 1, \mathrm{C} 3$ and $\mathrm{C} 4$ sites are all located within $7.5 \mathrm{~km}$, with a transition from $\mathrm{C} 1$ to $\mathrm{C} 4$ within only $4 \mathrm{~km}$ to the south-west of the town.

\section{Relationships between mean hydrographs and rainfall/river flow}

Mean hydrographs $\mathrm{C} 1, \mathrm{C} 2, \mathrm{C} 3$, and $\mathrm{C} 4$ are strongly, moderately, weakly and very weakly correlated, respectively, with SPI for a given accumulation period (Fig. 6; Table 2). For MH $\mathrm{C} 1$ the correlation increases with SPI accumulation periods for SPI at Mara up to the maximum of 36 months, and increases with accumulation periods for SPI at Bela-Bela before peaking at 25 months. The correlation coefficient $(r)$ is 0.63 and 0.52 for Bela-Bela and Mara, respectively, by $k=12$. For MHs C2 and C3, the correlation with SPI increases with accumulation period up to around 5-10 months, before declining, then increasing again and peaking at 21-35 months. For $\mathrm{MH} \mathrm{C} 4$, the most correlated accumulation periods are much shorter (2-3 months), although given the weakness of the relationship, it is challenging to contrast this value with the other cluster accumulation periods.

Increasing lag in SPI reduces correlations for $\mathrm{C} 1$. The optimal lags for $\mathrm{C} 2$ and $\mathrm{C} 3$ are a month or two months, respectively, with further lags reducing the correlation. The optimal lags are more inconsistent for $\mathrm{C} 4$ at 2-6 months. Maximum correlation coefficients are reasonably consistent for both rainfall sites (Table 2).

MHs C2, C3, and $\mathrm{C} 4$ are more strongly correlated with SSI than SPI, with $\mathrm{C} 2$ and $\mathrm{C} 4$ being the most and least correlated, respectively (Fig. 6; Table 2). MH $\mathrm{C} 1$ is similarly correlated with both SSI and SPI. The most correlated accumulation periods and lags for each cluster are similar for both SSI and SPI (Table 2). Therefore, there is evidence that groundwater storage variations are more statistically related to river flow dynamics than rainfall dynamics for $\mathrm{C} 2, \mathrm{C} 3$, and $\mathrm{C} 4$, but not $\mathrm{C} 1$.

\section{Relationships between mean hydrographs and ENSO}

There is a negative relationship between mean wet season MEI and the change in SGI for all clusters (Fig. 7). The greatest increases in SGI generally occurred during the negative ENSO (La Niña) years of 1996 and 2000 and there was no increase in SGI during the most positive ENSO (El Niño) years (MEI > 1.5). Negative MEI does not necessarily relate to rises in the water table over the wet season-for example, in 1989, which had the strongest negative anomaly, rainfall was $316 \mathrm{~mm}$ in Mara and groundwater levels did not rise over the wet season in any cluster. There is a more consistent tendency for groundwater levels not to rise during strongly positive ENSO years.

The nonparametric correlation coefficients are most negative and only significant $(p<0.05)$ for $\mathrm{C} 3$ and $\mathrm{C} 4$ (Fig. 7). Wet season increases in SGI at $\mathrm{C} 3$ and $\mathrm{C} 4$ are only evident when MEI $<0.4$. C1 consistently rises across a much broader range of MEI values compared to the other MHs. Additionally, C1 does not respond as appreciably as the other MHs to the 2000 event, with the magnitude of the response being comparable to several other years. The 1996 and 2000 wet season increases in SGI are greatest at $\mathrm{C} 2$, but there is no clear relationship with ENSO with those years omitted.

\section{Discussion}

\section{Factors controlling cluster types}

\section{Rainfall and aridity}

Rainfall and aridity are a key control on groundwater hydrographs and recharge across the continent (Cuthbert et al. 2019; MacDonald et al. 2021). There is some evidence for a transition from either $\mathrm{C} 1$ or $\mathrm{C} 2$ to $\mathrm{C} 3$ or $\mathrm{C} 4$ down both catchments. Any downstream transition could relate to rainfall variability, particularly given the nonlinearity observed between rainfall and recharge in the continent, whereby small increases in annual rainfall in excess of a given threshold can lead to substantial rises in recharge (Taylor et al. 2013). However, there is minimal evidence for lower annual rainfall at $\mathrm{C} 3$ and $\mathrm{C} 4$ sites compared with $\mathrm{C} 1$ and $\mathrm{C} 2$ sites, although lowest annual rainfall does occur at site 19 (C4) (Fig. 8a; Fig. S3 of the ESM). Furthermore, the aridity index displays no appreciable variation between clusters despite varying between 0.24 and 0.38 at the sites (Fig. 8b; Fig. S4 of the ESM). It should also be reiterated that changes in hydrograph type also occur over short distances where any climate variation is negligible. Consequently, there is limited evidence for rainfall and aridity differentiating between the hydrograph clusters, and other local drivers are important. 


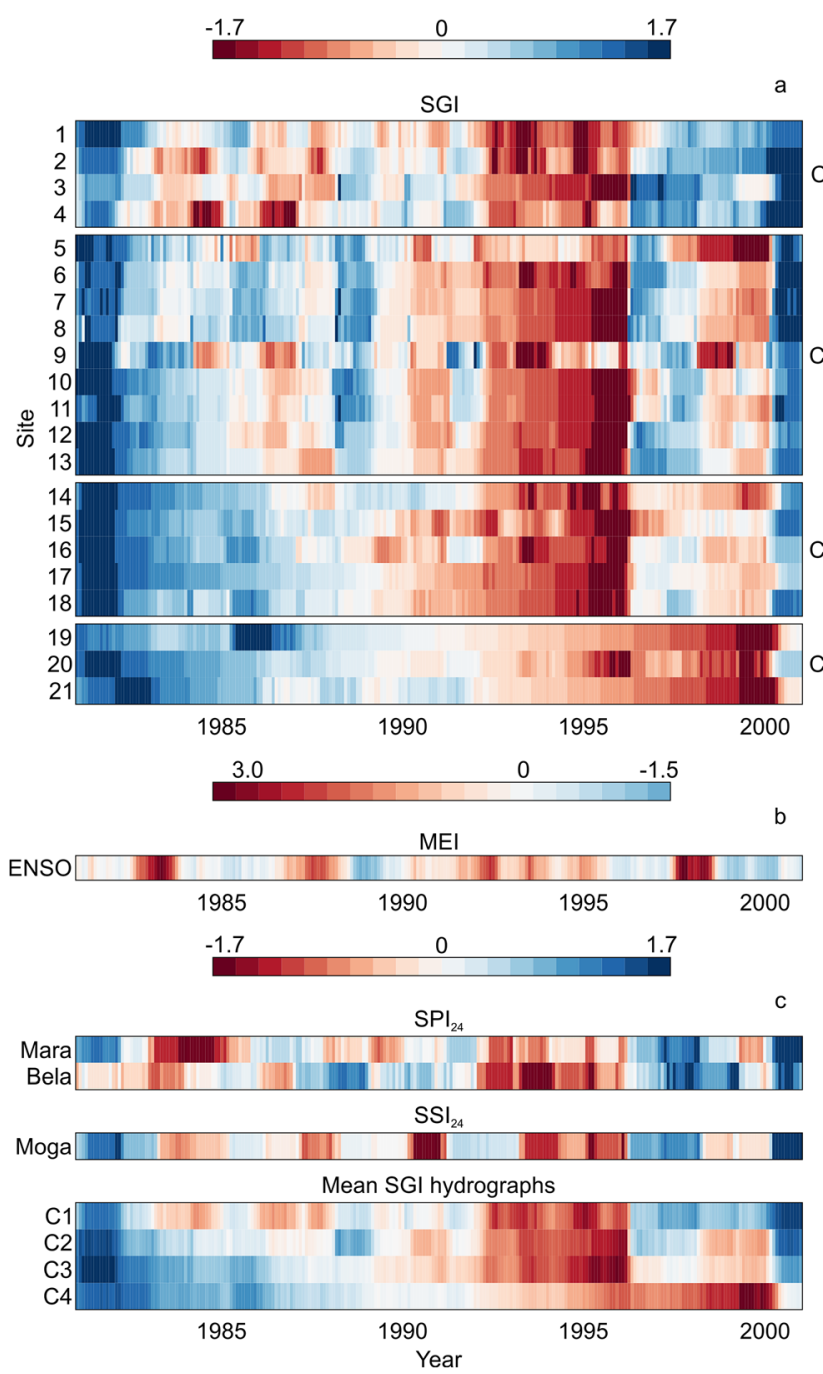

Fig. 4 a All SGI time series grouped by cluster (C1-C4); b ENSO anomalies represented by the MEI; and $\mathbf{c} \mathrm{SPI}_{24}$ at Mara and Bela (BelaBela), $\mathrm{SSI}_{24}$ at Moga (Mogalakwena), and SGI of the MH for each cluster

\section{Hydrogeology}

In semi-arid climates, groundwater recharge is often postulated to occur beneath riverbeds (Cuthbert et al. 2016; Meredith et al. 2015; Scanlon et al. 2006), therefore, one may expect sites further from rivers to be less dynamic, with longer autocorrelation. However, Van Wyk (2010) demonstrated hydrographs did not adhere to this suggested model in crystalline rock settings in South Africa with more dynamic hydrographs observed away from rivers in more upland settings where soils and regoliths were thinner. In terms of the hydrographs from this study, two of the three sites furthest from a river are in C4 (Fig. 8c). Moreover, site 19, the only C4 type near a river (ca. $400 \mathrm{~m}$ ), lies close to only a small tributary of the Mogalakwena, which is likely to flow less frequently than the main channel with a comparably smaller catchment area. There is also evidence for a transition from $\mathrm{C} 1$ types (sites 4, 2, 1), to C3 type (site 15) and then C4 type (site
20) as you move approximately perpendicular away from the river running through Polokwane (Fig. 5). Nevertheless, there are also inconsistencies in these relationships - for example, site 18 (C3) also lies close to the river in Polokwane, the second furthest site from the river is a C1 type (site 3), and there is no clear variation in distance from nearest surface water between C1, C2, and C3 (Fig. 8c).

A deeper unsaturated zone can smooth groundwater level changes and increase the autocorrelation structure; however, groundwater levels were similar across C1, C2, and C3 types, with the deepest mean groundwater levels across all sites actually at a C2 type (site 8) $41.5 \mathrm{~m}$ below datum (bd). There is evidence for generally deeper groundwater levels at $\mathrm{C} 4$ types (Fig. 8d), partially a result of the declining trend in levels over the study period (Fig. S5 of the ESM).

There is no relationship between cluster type and geology (Fig. 5). All four cluster types occur in the Archaean gneiss/ granite (Fig. 5), including $\mathrm{C} 1, \mathrm{C} 3$ and $\mathrm{C} 4$ types in close proximity around Polokwane. Types C2, C3, and C4 also all occur in the Rustenburg Layered Suite. It is unclear whether boreholes are screened within the overburden or bedrock, which could behave differently, although it is common practice to screen boreholes across water strikes in both the regolith and fractured rock. Furthermore, there is uncertainty over variations in hydraulic conductivity and storage between sites, as well as the potential of structural controls, principally dykes and faults, on the hydrogeology, which could restrict groundwater flow (Ebrahim et al. 2019). Therefore, there is potential to have compartmentalised aquifer units (Abiye et al. 2020) that are less dynamic within the same broad geological classification.

\section{Abstraction and land use}

There are concerns in both catchments regarding the high abstraction of groundwater (Abiye et al. 2020; Busari 2008; DWAF 2004; DWS 2015; Masiyandima et al. 2002). Abstraction has the potential to introduce downward trends in hydrographs (Oiro et al. 2020) and increase autocorrelation (Wendt et al. 2020). Pivot irrigation is well developed in the study area (Cai et al. 2017; Ebrahim et al. 2019), particularly north of Polokwane in the Sand Catchment (Fig. 9), which is mainly reliant on groundwater. Specifically, around Mogwadi, near site 21 (C4), it is reported that pivot irrigation for commercial agriculture has reduced groundwater levels by $50 \mathrm{~m}$ between the 1970s and 2000 (Fallon et al. 2019; Masiyandima et al. 2002) and satellite imagery confirms extensive pivot irrigation encircling the site (Fig. S6a of the ESM). More localised pivot irrigation is also proximal to sites 18 and 16 (C3; Fig. 9). There is a mixture of pivot irrigation and medium- to high-intensive commercial agriculture, presumably irrigated by other means, around site 19 (C4) (Fig. 9; Fig. S6b of the ESM). Some C1 and C2 sites (e.g. 3, 5, 12) are 


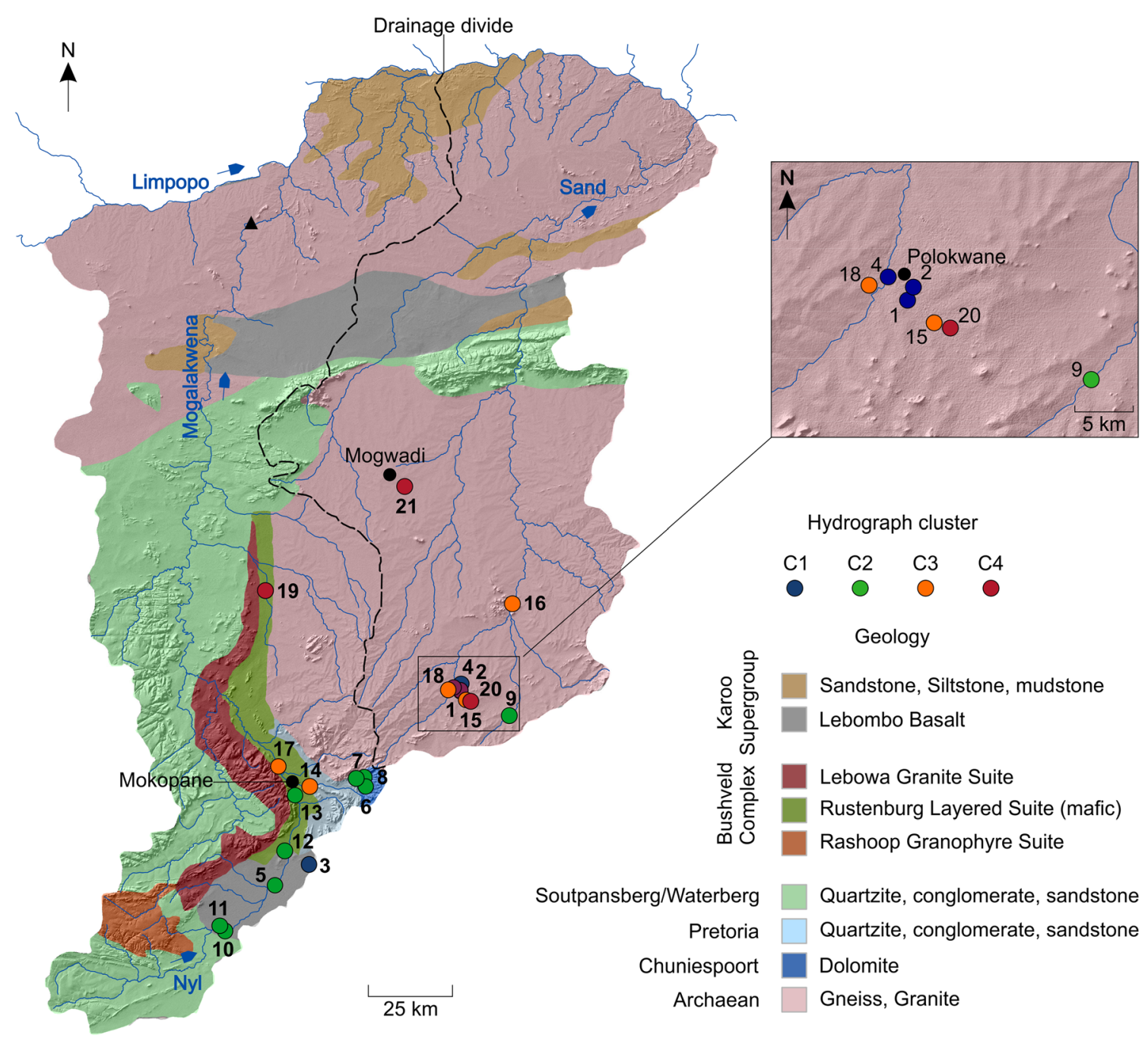

Fig. 5 Spatial distribution of clustered borehole sites in the study area. Geology simplified from the 1:1000000 map of South Africa (Council for Geoscience 2019). Blue arrows indicate surface-water flow direction

located in areas of commercial agriculture, but this is predominately classed as low-intensive. Therefore, sites in areas of pivot irrigation and medium- to high-intensive commercial agriculture appear to be in $\mathrm{C} 3$ and $\mathrm{C} 4$.

Groundwater in the Polokwane Municipality is some of the most highly utilised in the study area and a previous water balance by the DWS stated it was $>300 \%$ overexploited in 2010 (DWS 2016). The municipal water supply to the town has been mainly imported from neighbouring dammed surface water catchments since 1958 because groundwater was unable to sustain the growing demand (Vegter 2003). Groundwater still provided a subordinate component that varied between 2.17 and 4.01 million $\mathrm{m}^{3} /$ year during the study period (Vegter 2003). Sites 15 (C3) and 20 (C4) are both located in the Sterkloop Wellfield, whilst sites 18 (C3) and 4 (C1) are just outside the Sand River Wellfield. Sites 1 (C1) and 2 (C1) lie within the urban conurbation (Fig. 9).

There is mining and smelting activity around Polokwane, with site 20 being within $2.5 \mathrm{~km}$ of this land use (Fig. 9), although the extent of groundwater use by these industries is unknown. The town also operates a managed aquifer recharge (MAR) scheme, but this is located north of Polokwane (Fig. 9) and produces an undulating water table in boreholes only downstream of the scheme (Murray and Tredoux 2002). The association of types $\mathrm{C} 3$ and $\mathrm{C} 4$ with the Polokwane wellfields, as opposed to the $\mathrm{C} 1$ sites located within only $2 \mathrm{~km}$ of these sites and outside the wellfields, indicates municipal abstraction may be an important control on groundwater hydrographs locally.

Groundwater resources are also under pressure around Mokopane, where there is a shift from $\mathrm{C} 2$ to $\mathrm{C} 3$ sites in the Mogalakwena Catchment. Notably, groundwater levels have been declining around the Mokopane wellfield (Busari 2008), although it is unclear if it is the wellfield itself which has led to the declining water table. Mining is a large employer in the town, including the largest open pit platinum mine in the world north of the town. The extensive workings are large water consumers, although the mine is downstream of the 


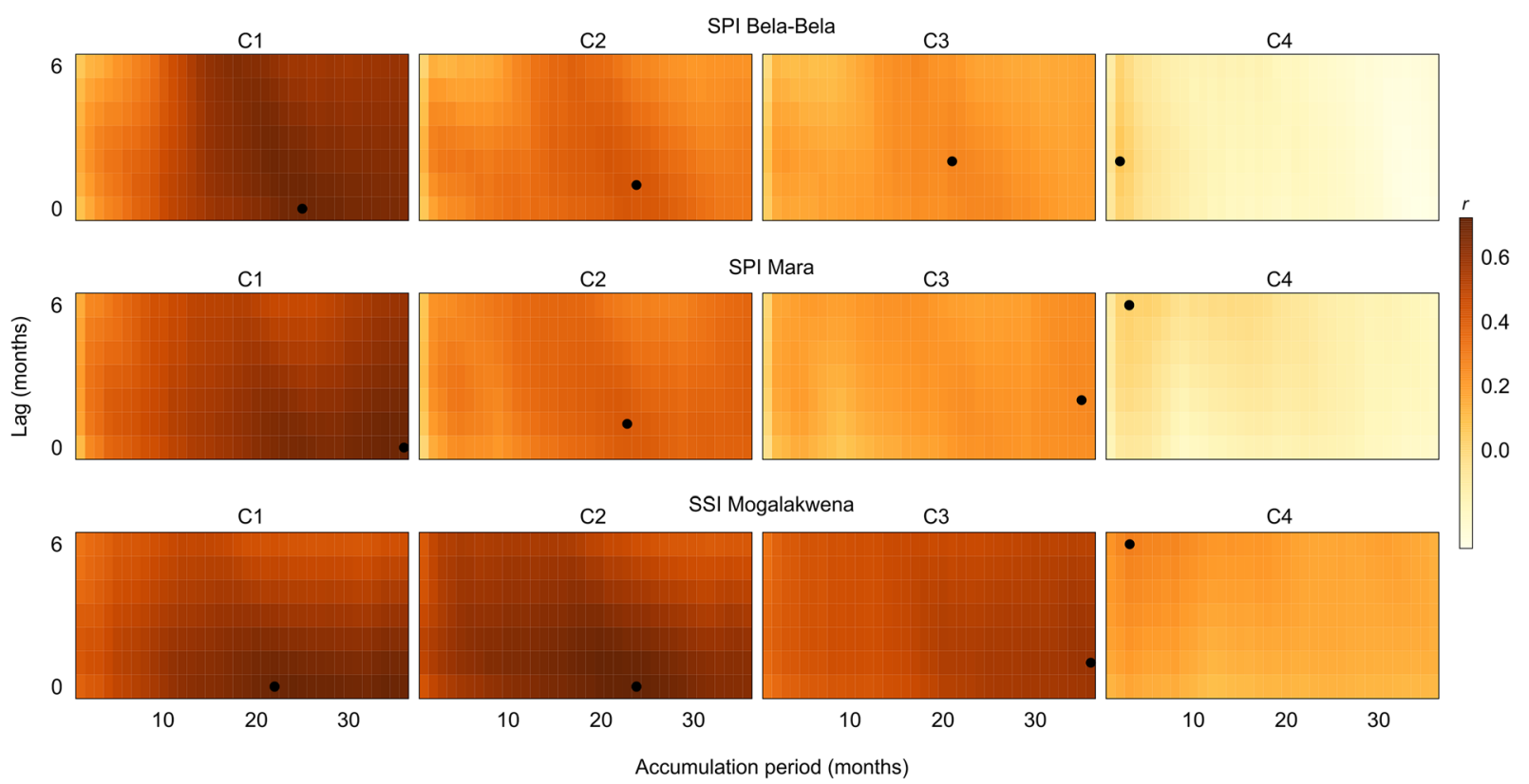

Fig. 6 Correlation heat maps for each of the four mean hydrographs (MHs) for a range of accumulation periods and lags of SPI Bela-Bela, SPI Mara, and SSI Mogalakwena. Black dots mark the highest Pearson's correlation coefficient $(r)$

C3 sites. Furthermore, it should be noted that given the water pressures in both catchments, several mines have switched to utilising grey water from both the Mokopane and Polokwane wastewater treatment works.

\section{Evidence for recharge processes}

Stronger relationships between groundwater levels and river flow than groundwater levels and rainfall for C2, C3 and C4 may suggest that groundwater recharge is dominated by leakage from surface water at those sites. The Polokwane MAR scheme makes use of the interconnected Sand River, alluvial aquifer, and bedrock aquifers where treated municipal

Table 2 Maximum correlation $(r)$ between SGI and SPI for a range of accumulation periods (k) and lags up to 6 months

\begin{tabular}{|c|c|c|c|c|}
\hline Data & Cluster & $r$ & $\mathrm{SPI} / \mathrm{SSI}_{\mathrm{k}}$ (months) & Lag (months) \\
\hline \multirow[t]{4}{*}{ SPI Bela-Bela rainfall } & $\mathrm{C} 1$ & 0.70 & 25 & 0 \\
\hline & $\mathrm{C} 2$ & 0.45 & 22 & 1 \\
\hline & $\mathrm{C} 3$ & 0.29 & 21 & 2 \\
\hline & $\mathrm{C} 4$ & 0.10 & 2 & 2 \\
\hline \multirow[t]{4}{*}{ SPI Mara } & $\mathrm{C} 1$ & 0.71 & 36 & 0 \\
\hline & $\mathrm{C} 2$ & 0.44 & 23 & 1 \\
\hline & $\mathrm{C} 3$ & 0.28 & 35 & 2 \\
\hline & $\mathrm{C} 4$ & 0.07 & 3 & 6 \\
\hline \multirow[t]{4}{*}{ SSI Mogalakwena } & $\mathrm{C} 1$ & 0.71 & 22 & 0 \\
\hline & $\mathrm{C} 2$ & 0.72 & 24 & 0 \\
\hline & $\mathrm{C} 3$ & 0.60 & 36 & 1 \\
\hline & $\mathrm{C} 4$ & 0.31 & 3 & 6 \\
\hline
\end{tabular}

wastewater discharges to the river to recharge the bedrock aquifer that is then tapped for public water supply and agriculture (Murray and Tredoux 2002). However, Walker et al. (2018) concluded the 2-m-thick alluvial deposits beneath a reach of the Molotsi sand river, a bordering catchment to the Sand River with similar geology, were hydraulically unconnected to the underlying fractured basement. Furthermore, along the Nyl River, an upstream tributary of the Mogalakwena (Fig. 5), Tooth et al. (2002) reported that flooding had effectively sealed the floodplain with thin clay layers which limit groundwater recharge. They did note, though, that some recharge does occur at the margins of the floodplain where the superficial deposits are coarser.

Therefore, within the literature, there is a lack of consistent local studies that support widespread surface water and groundwater connectivity, let alone the suggested dominance of focussed recharge from surface waters. An equally plausible explanation of the relationship between SGIs and SSI is that both river flow and groundwater recharge are an expression of soil moisture excess in the catchments and therefore related only indirectly. The SGI and SSI relationship could also theoretically indicate a groundwater-fed river network, but this is unlikely in the local conditions where baseflow is a minor component of streamflow.

\section{Importance of teleconnections and extreme events}

The relationship to ENSO is strongest for MHs C3 and C4. It is suggested here that the stronger relationship is a combination of two factors. Firstly, frequent recharge signals that are unrelated to a particularly strong/weak ENSO are masked by 


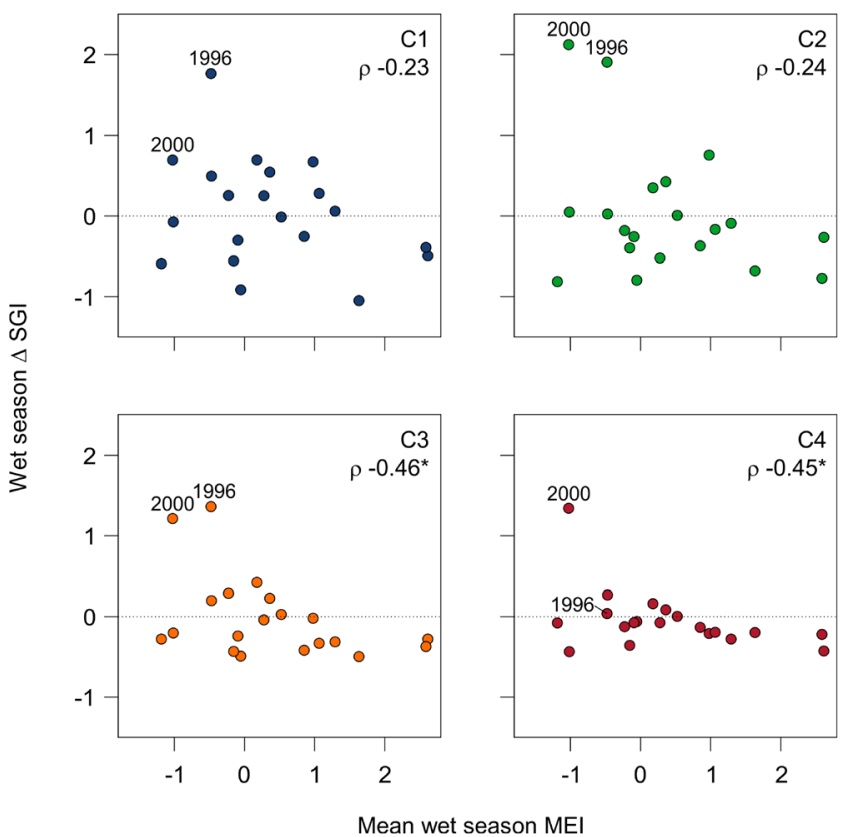

Fig. 7 Wet season mean Multivariate ENSO Index (MEI. v2) versus change in SGI for all clusters highlighting two wet season periods of anomalously high rainfall. Correlation is assessed by Spearman's Rank, $n=20$, and $*$ denotes significance at $p<0.05$

abstraction. Secondly, the lowering of the water table over several years by abstraction may increase available subsurface storage resulting in a more notable rise in the water table when extreme ENSO-driven rainfall events occur. Evidence for this latter factor can be drawn from the contrasting responses to the extreme rainfall event of 2000. SGIs in 2000 for C3 and C4 MHs rose substantially but did not achieve their maxima following years of predominantly groundwater recession. On the other hand, the magnitude of the rise in the $\mathrm{C} 1 \mathrm{MH}$ was comparable to multiple other years, despite the extreme nature of the rainfall, and the SGI peaked. Examination of the raw groundwater level data from three sites $(1,2$, and 4$)$ of the four $\mathrm{C} 1$ sites demonstrates that water levels in the 2000 wet season were around their peaks across their entire records (up
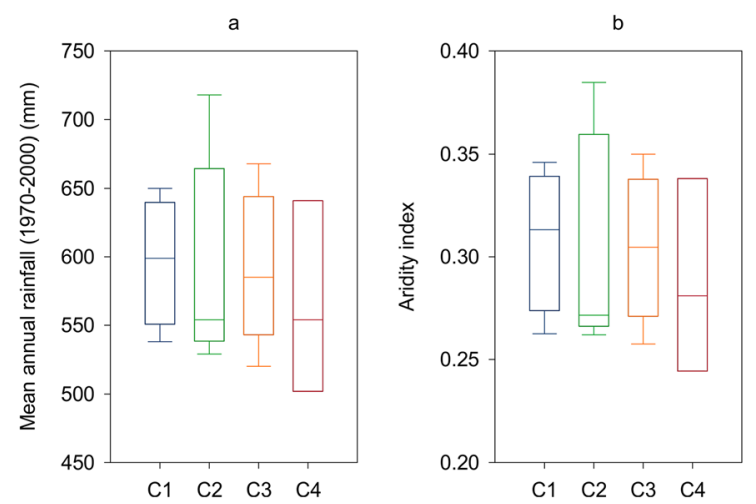

Fig. 8 Hydrogeological similarities between hydrograph clusters: a mean annual rainfall (Fick and Hijmans 2017), b aridity index (Trabucco and Zomer 2018), c distance to surface water, $\mathbf{d}$ groundwater level in metres to 40 years) and relatively shallow $(6.9,2.9,2.6 \mathrm{~m}$ below datum; Fig. S5 of the ESM). This evidence may indicate the response to the 2000 event at some $\mathrm{C} 1$ sites may had been storage limited. It is also possible that at such shallow water depths in these crystalline rock settings, there are layers within the soils of very high permeability that could initiate rapid lateral flows and restrict further rises in levels (Bonsor et al. 2014). Vertical variability in specific yield could be significant in terms of recharge response and the mean water levels prior to the event differed for $\mathrm{C} 1$ to $\mathrm{C} 4$ at $8.2,16.1,12.2$ and $29.3 \mathrm{~m} \mathrm{bd}$, respectively. However, there is no information on weathering thickness or lithology from the individual boreholes to assess vertical contrasts in specific yield.

Long-term groundwater hydrographs elsewhere in the continent, that tend to be located in wellfields, display similar behaviour to $\mathrm{C} 3$ and $\mathrm{C} 4$, such as the 60-year hydrographs from the Dodoma wellfield, Tanzania (Taylor et al. 2013). Such datasets from areas of high abstraction may overemphasise the importance of recharge from extreme events, as well as teleconnections, compared to more natural settings. Indeed, recent modelling work by Seddon (2019) for the Dodoma wellfield does show that accounting for the influence of abstraction on groundwater levels hydrographs does reduce the number of years reporting zero recharge. Nevertheless, their analysis still demonstrates heavy rainfalls contribute disproportionately to recharge and extreme events are undoubtedly invaluable from a water security perspective in Africa.

The major recharge events for all hydrographs types are associated with extreme rainfall occurring during negative ENSO years. The 1996 event is highly pronounced within C1, C2, and C3 MHs, and follows the early 1990s drought where groundwater levels had fallen widely. It is unclear why two of the C4 types (sites 19 and 21) do not respond to this event, but they are furthest downstream and distant from the main river channels. The more substantial 2000 event triggered strong responses in all types.
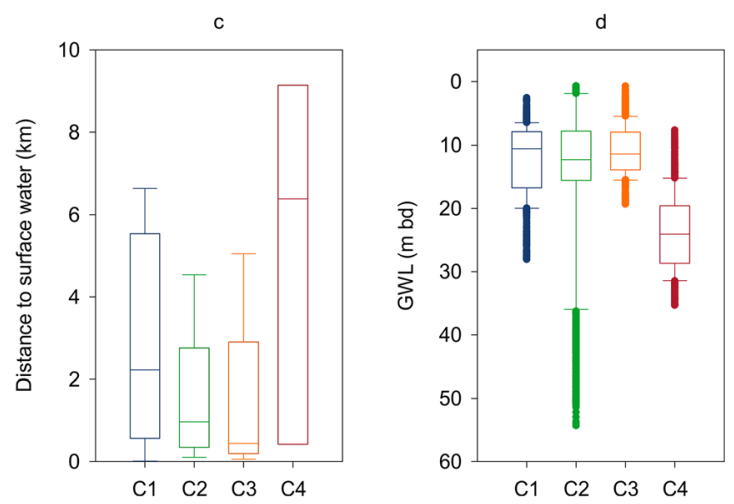

below datum ( $\mathrm{m}$ bd) during study period. Boxes illustrate the 25 and 75 th percentiles, dissected by the median; whiskers indicate the 10th and 90th percentiles; and all outliers are shown as dots 


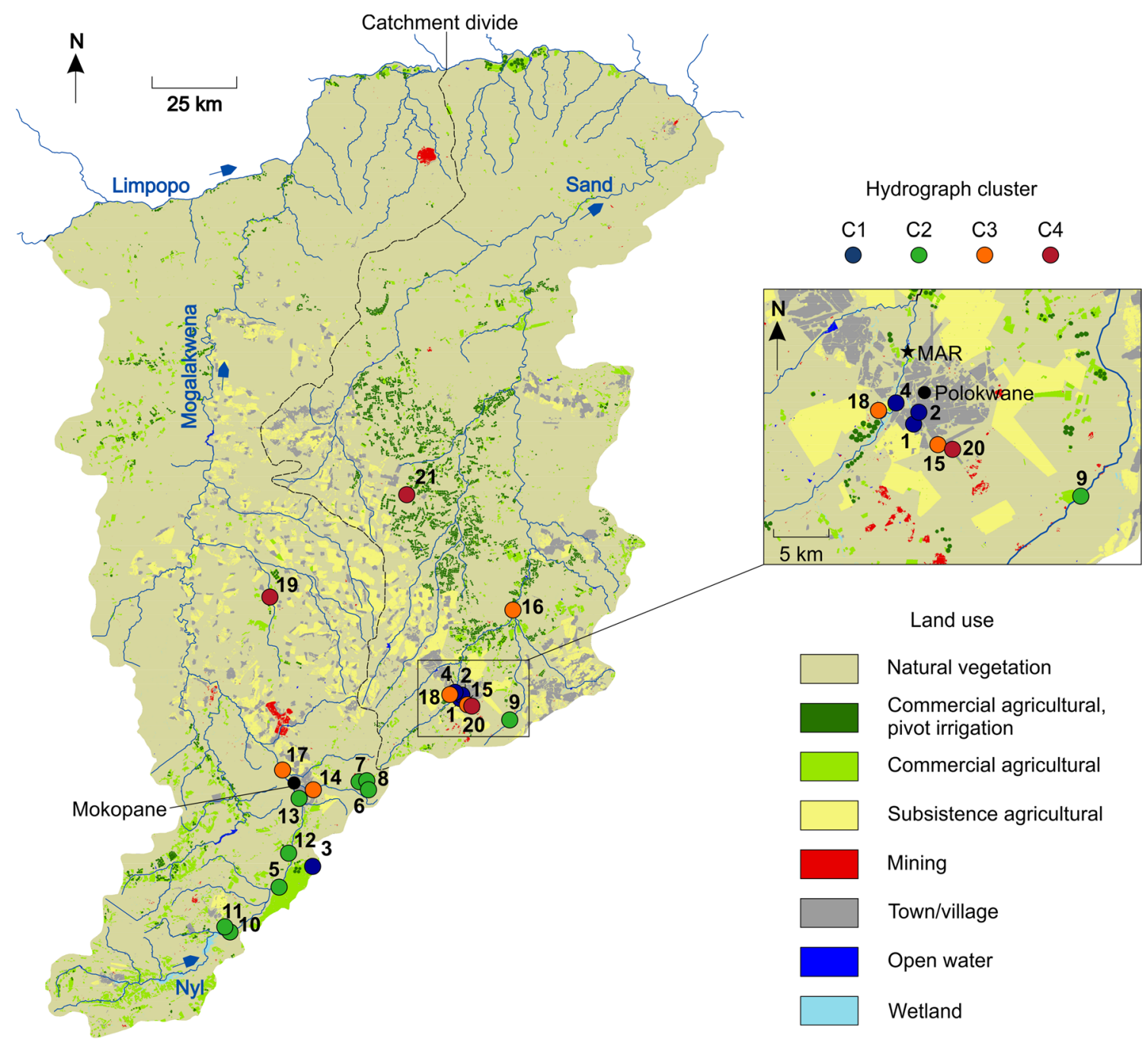

Fig. 9 Simplified land use classification of the study area (DAFF 2015) displaying all sites coloured by cluster type. MAR on the inset figure corresponds to the Polokwane Managed Aquifer Recharge scheme

There is consistent evidence across all cluster types that groundwater levels do not rise during extreme positive ENSO years. This is supported by an analysis of ENSO and rainfall in Limpopo Province, which demonstrated a robust positive relationship between ENSO anomalies (Niño 3.4 sea surface temperature) and dry spell frequency between 1979 and 2002 (Reason et al. 2005). ENSO anomalies could also be used to predict groundwater recharge, given that model predictions of rainfall in southern Africa can be improved by the inclusion of ENSO (Kolusu et al. 2019; Landman and Beraki 2012).

\section{Conclusions}

Twenty-one groundwater hydrographs in two adjacent semi-arid (0.24-0.38 aridity index) catchments in South
Africa, from 1980 to 2000 when records overlapped, were classified into four cluster types (C1-C4). Hydrograph types $\mathrm{C} 1$ through to $\mathrm{C} 4$ show a transition of increasing autocorrelation and increasingly subdued rainfall responses. $\mathrm{C} 1$ type is strongly related to rainfall, has the optimal cross-correlation with the standardised precipitation index (SPI), fluctuates on a typically annual basis, and has significant $(p<0.05)$ positive autocorrelation of 28 months. $\mathrm{C} 4$ type is minimally related to rainfall and characterised by multiannual recessions with a significant positive autocorrelation of 70 months with levels rising only in response to an extreme rainfall event in 2000. $\mathrm{C} 2$ and $\mathrm{C} 3$ types are intermediates between the $\mathrm{C} 1$ and $\mathrm{C} 4$ extremes.

C1 type is similarly related to both the SPI and the standardised streamflow index (SSI), whereas $\mathrm{C} 2-\mathrm{C} 4$ are more strongly associated with SSI. These correlations may suggest $\mathrm{C} 2-\mathrm{C} 4$ are more dependent on focussed recharge from riverbeds, though further investigation using 
environmental tracers is required to confirm this assertion as river flow and diffuse recharge are both driven by an excess of soil moisture.

There is a tendency for substantial or minimal recharge to occur during extreme negative and positive ENSO years, respectively, thus ENSO anomalies could be useful to predict groundwater recharge. Large recharge events occur in 1996 and 2000 during negative ENSO years (La Niña), though large recharge events do not always occur during such years. Declines in the water table are associated with extreme positive ENSO years (MEI > 1.5). Only SGI changes in C3 and $\mathrm{C} 4$ types are significantly correlated with wet season El Niño-Southern Oscillation (ENSO) anomalies across the study period.

The range of groundwater hydrograph types, sometimes within only a few kilometres, cannot be attributed to spatial variability in either climate or hydrogeological settings such as distance to surface water, depth to water table, or available geological information. C3 and C4 sites appear to be associated with areas of high groundwater abstraction such as municipal wellfields and intensive commercial agriculture. It is considered that high levels of abstraction near $\mathrm{C} 3$ and $\mathrm{C} 4$ sites mask frequent small-scale recharge events observed at $\mathrm{C} 1$ and $\mathrm{C} 2$ sites. Lowering of water levels by abstraction may also increase available storage resulting in greater capture of recharge from extreme events and/or produce contrasting hydrograph responses to recharge due to vertical variability in aquifer properties. Consequently, extreme events associated with positive ENSO years are most notable in the $\mathrm{C} 3$ and $\mathrm{C} 4$ time series.

Abstraction can bias interpretations of groundwater hydrographs concerning: the regularity of recharge, the relative importance of extreme recharge events, the strength of the relationship with the potential recharge drivers of rainfall and streamflow, and the significance of teleconnections. Therefore, care should be taken when analysing groundwater level data from areas of high abstraction such as within municipal wellfields or near intensively irrigated agriculture.

Supplementary Information The online version contains supplementary material available at https://doi.org/10.1007/s10040-021-02391-3.

Acknowledgements South African groundwater level data and rainfall data from climate stations were kindly provided by the Department of Water and Sanitation (DWS) and South African Weather Service (SAWS), respectively. Jennifer Bow (BGS) supported in the production of Figs. 1, 5 and 9.

Funding The authors acknowledge support from the NERC-ESRCDFID UPGro programme under the GroFutures Project (NE/M008932/ 1, NE/M008622/1) and the CGIAR Research Program on Water, Land and Ecosystems (WLE). JPRS, AMM, and MJA acknowledge additional support from the British Geological Survey NC-ODA grant NE/ R000069/1: Geoscience for Sustainable Futures. MOC gratefully acknowledges funding for an Independent Research Fellowship from the UK Natural Environment Research Council (NE/P017819/1). JL and KHJ acknowledge the support provided by the Ministry of Foreign Affairs of Denmark via the Danida Fellowship Centre to the project Enhancing Sustainable Groundwater Use in South Africa (ESGUSA).

\section{Declaration}

Conflict of interest On behalf of all authors, the corresponding author states that there is no conflict of interest.

Open Access This article is licensed under a Creative Commons Attribution 4.0 International License, which permits use, sharing, adaptation, distribution and reproduction in any medium or format, as long as you give appropriate credit to the original author(s) and the source, provide a link to the Creative Commons licence, and indicate if changes were made. The images or other third party material in this article are included in the article's Creative Commons licence, unless indicated otherwise in a credit line to the material. If material is not included in the article's Creative Commons licence and your intended use is not permitted by statutory regulation or exceeds the permitted use, you will need to obtain permission directly from the copyright holder. To view a copy of this licence, visit http://creativecommons.org/licenses/by/4.0/.

\section{References}

Abiye TA, Tshipala D, Leketa K, Villholth K, Magombeyi M, Ebrahim G, Butler M (2020) Hydrogeological characterization of crystalline aquifer in the Hout River catchment, Limpopo province. South Africa Groundwater for Sustainable Development 100406. Groundw Sustain Devel 11:100406. https://doi.org/10.1016/j.gsd. 2020.100406

Altchenko Y, Villholth KG (2015) Mapping irrigation potential from renewable groundwater in Africa: a quantitative hydrological approach. Hydrol Earth Syst Sci 19(2):1055-1067

Ascott M, Macdonald D, Black E, Verhoef A, Nakohoun P, Tirogo J, Sandwidi W, Bliefernicht J, Sorensen J and Bossa A (2020) In-situ observations and lumped parameter model reconstructions reveal intra-annual to multi-decadal variability in groundwater levels in sub-Saharan Africa. Water Resour Res 56(12):e2020WR028056

Barker LJ, Hannaford J, Chiverton A, Svensson C (2016) From meteorological to hydrological drought using standardised indicators. Hydrol Earth Syst Sci 20(6):2483-2505

Bloomfield J, Marchant B (2013) Analysis of groundwater drought building on the standardised precipitation index approach. Hydrol Earth Syst Sci 17:4769-4787

Bloomfield J, Marchant B, Bricker S, Morgan R (2015) Regional analysis of groundwater droughts using hydrograph classification. Hydrol Earth Syst Sci 19(10):4327-4344

Bonsor H, MacDonald A, Davies J (2014) Evidence for extreme variations in the permeability of laterite from a detailed analysis of well behaviour in Nigeria. Hydrol Process 28(10):3563-3573

Braune E, Xu Y (2010) The role of ground water in sub-Saharan Africa. Groundwater 48(2):229-238

Busari O (2008) Groundwater in the Limpopo Basin: occurrence, use and impact. Environ Dev Sustain 10(6):943-957

Cai X, Magidi J, Nhamo L, van Koppen B (2017) Mapping irrigated areas in the Limpopo Province, South Africa. International Water Management Institute, Colombo, Sri Lanka

Cobbing J, Hiller B (2019) Waking a sleeping giant: realizing the potential of groundwater in sub-Saharan Africa. World Dev 122:597-613 
Council for Geoscience (2019) RSA 1:1 000 000-scale geological map of South Africa. https://www.geoscience.org.za/index.php/mapdownloads/130-map-download. Accessed July 2021

Crimp S, Mason S (1999) The extreme precipitation event of 11 to 16 February 1996 over South Africa. Meteorog Atmos Phys 70(1-2): $29-42$

Cuthbert M, Acworth R, Andersen M, Larsen J, McCallum A, Rau G, Tellam J (2016) Understanding and quantifying focused, indirect groundwater recharge from ephemeral streams using water table fluctuations. Water Resour Res 52(2):827-840

Cuthbert MO, Taylor RG, Favreau G, Todd MC, Shamsudduha M, Villholth KG, MacDonald AM, Scanlon BR, Kotchoni DV, Vouillamoz J-M (2019) Observed controls on resilience of groundwater to climate variability in sub-Saharan Africa. Nature 572 (7768):230-234

DAFF (2015) South Africa field boundaries map. Department of Agriculture, Forestry and Fisheries, Government of South Africa, Pretoria, South Africa

Döll P, Fiedler K (2008) Global-scale modeling of groundwater recharge. Hydrol Earth Syst Sci 12(3):863-885

du Toit WH (2003) Hydrogeological map series of the Republic of South Africa, Phalaborwa 2330 sheet (1:500000). Government Printer, Pretoria, South Africa

DWAF (2004) Internal strategic perspective: Limpopo water management area. Report no. P WMA 01/000/00/0304. DWS, Gov. of South Africa, Pretoria

DWS (2015) The development of the Limpopo water management area north reconciliation strategy: hydrological analysis, vol 1. DWS, Gov. of South Africa, Pretoria

DWS (2016) Limpopo Water Management Area north reconciliation strategy. Draft reconciliation strategy. P WMA 01/000/00/02914/ 11A. https://static.pmg.org.za/RNW245-2020-06-19-Annexure_B. pdf. Accessed July 2021

Dyson L, Van Heerden J (2001) The heavy rainfall and floods over the northeastern interior of South Africa during February 2000. S Afr J Sci 97(3-4):80-86

Ebrahim GY, Villholth KG, Boulos M (2019) Integrated hydrogeological modelling of hard-rock semi-arid terrain: supporting sustainable agricultural groundwater use in Hout catchment, Limpopo Province, South Africa. Hydrogeol J 27(3):965-981

Fallon A, Villholth K, Conway D, Lankford B, Ebrahim G (2019) Agricultural groundwater management strategies and seasonal climate forecasting: perceptions from Mogwadi (Dendron), Limpopo, South Africa. J Water Clim Change 10(1):142-157

Fauchereau N, Pohl B, Reason C, Rouault M, Richard Y (2009) Recurrent daily OLR patterns in the southern Africa/Southwest Indian Ocean region, implications for south African rainfall and teleconnections. Clim Dyn 32(4):575-591

Favreau G, Cappelaere B, Massuel S, Leblanc M, Boucher M, Boulain N, Leduc C (2009) Land clearing, climate variability, and water resources increase in semiarid Southwest Niger: a review. Water Resour Res 45(7)

Fick SE, Hijmans RJ (2017) WorldClim 2: new 1-km spatial resolution climate surfaces for global land areas. Int J Climatol 37(12):43024315

Gaughan AE, Staub CG, Hoell A, Weaver A, Waylen PR (2016) Interand intra-annual precipitation variability and associated relationships to ENSO and the IOD in southern Africa. Int J Climatol 36 (4):1643-1656

Gaye CB, Tindimugaya C (2019) Challenges and opportunities for sustainable groundwater management in Africa. Hydrogeol J 27(3): 1099-1110

Haaf E, Barthel R (2018) An inter-comparison of similarity-based methods for organisation and classification of groundwater hydrographs. J Hydrol 559:222-237
Holland M (2011) Hydrogeological characterisation of crystalline basement aquifers within the Limpopo Province. University of Pretoria, Pretoria, South Africa

Holland M, Witthüser KT (2011) Evaluation of geologic and geomorphologic influences on borehole productivity in crystalline bedrock aquifers of Limpopo Province, South Africa. Hydrogeol J 19(5): $1065-1083$

Kolusu SR, Shamsudduha M, Todd MC, Taylor RG, Seddon D, Kashaigili JJ, Ebrahim GY, Cuthbert MO, Sorensen JPR, Villholth KG, MacDonald AM, MacLeod DA (2019) The El Niño event of 2015-2016: climate anomalies and their impact on groundwater resources in east and southern Africa. Hydrol Earth Syst Sci 23(3): $1751-1762$

Kotchoni DV, Vouillamoz J-M, Lawson FM, Adjomayi P, Boukari M, Taylor RG (2019) Relationships between rainfall and groundwater recharge in seasonally humid Benin: a comparative analysis of longterm hydrographs in sedimentary and crystalline aquifers. Hydrogeol J 27(2):447-457

Landman WA, Beraki A (2012) Multi-model forecast skill for midsummer rainfall over southern Africa. Int J Climatol 32(2):303-314

MacDonald AM, Bonsor HC, Dochartaigh BÉÓ, Taylor RG (2012) Quantitative maps of groundwater resources in Africa. Environ Res Lett 7(2):024009

MacDonald AM, Lark RM, Taylor RG, Abiye T, Fallas HC, Favreau G, Goni IB, Kebede S, Scanlon B, Sorensen JP (2021) Mapping groundwater recharge in Africa from ground observations and implications for water security. Environ Res Lett 16(3):034012

MacKellar N, New M, Jack C (2014) Observed and modelled trends in rainfall and temperature for South Africa: 1960-2010. S Afr J Sci 110(7-8):1-13

Masiyandima M, Van der Stoep I, Mwanasawani T, Pfupajena SC (2002) Groundwater management strategies and their implications on irrigated agriculture: the case of Dendron aquifer in Northern Province, South Africa. Phys Chem Earth, Parts A/B/C 27(11-22):935-940

McCarthy TS, Tooth S, Jacobs Z, Rowberry MD, Thompson M, Brandt D, Hancox PJ, Marren PM, Woodborne S, Ellery WN (2011) The origin and development of the Nyl River floodplain wetland, Limpopo Province, South Africa: trunk-tributary river interactions in a dryland setting. S Afr Geogr J 93(2):172-190

McKee TB, Doesken NJ, Kleist J (1993) The relationship of drought frequency and duration to time scales. American Meteorological Society, Boston, MA, pp 179-183

Meredith K, Hollins S, Hughes C, Cendón D, Chisari R, Griffiths A, Crawford J (2015) Evaporation and concentration gradients created by episodic river recharge in a semi-arid zone aquifer: insights from $\mathrm{Cl}^{-}, \delta 18 \mathrm{O}, \delta 2 \mathrm{H}$, and 3H. J Hydrol 529:1070-1078

Murray E, Tredoux G (2002) Pilot artificial recharge schemes: testing sustainable water resource development in fractured aquifers. WRC Report 967-1-02, Water Research Commission. http://www. wrc.org.za/wp-content/uploads/mdocs/967-1-02.pdf. Accessed July 2021

Murray R, Louw D, van der Merwe B, Peters I (2018) Windhoek, Namibia: from conceptualising to operating and expanding a MAR scheme in a fractured quartzite aquifer for the city's water security. Sustain Water Resour Manag 4(2):217-223

Nieuwoudt WL, Backeberg G, Du Plessis H (2004) The value of water in the south African economy: some implications. Agrekon 43(2):162183

NOAA (2020) Multivariate ENSO index version 2 (MEI.v2). https:// www.psl.noaa.gov/enso/mei/. Accessed December 2020

Oiro S, Comte JC, Soulsby C, MacDonald A, Mwakamba C (2020) Depletion of groundwater resources under rapid urbanisation in Africa: recent and future trends in the Nairobi aquifer system, Kenya. Hydrogeol J 28:2635-2656 
Opie S, Taylor RG, Brierley CM, Shamsudduha M, Cuthbert MO (2020) Climate-groundwater dynamics inferred from GRACE and the role of hydraulic memory. Earth Syst Dynam 11(3):775-791

Owor M, Taylor R, Tindimugaya C, Mwesigwa D (2009) Rainfall intensity and groundwater recharge: empirical evidence from the upper Nile Basin. Environ Res Lett 4(3):035009

R Core Team (2017) R: a language and environment for statistical computing. R Foundation for Statistical Computing, Vienna, Austria. https://www.R-project.org/. Accessed July 2021

Reason C, Hachigonta S, Phaladi R (2005) Interannual variability in rainy season characteristics over the Limpopo region of southern Africa. Int J Climatol 25(14): 1835-1853

Scanlon BR, Keese KE, Flint AL, Flint LE, Gaye CB, Edmunds WM, Simmers I (2006) Global synthesis of groundwater recharge in semiarid and arid regions. Hydrol Proc 20(15):3335-3370

Seddon D (2019) The climate controls and process of groundwater recharge in a semi-arid tropical environment: evidence from the Makutapora Basin, Tanzania. University College London, UK

Sibanda T, Nonner JC, Uhlenbrook S (2009) Comparison of groundwater recharge estimation methods for the semi-arid Nyamandhlovu area, Zimbabwe. Hydrogeol J 17(6):1427-1441

Siebert S, Burke J, Faures J-M, Frenken K, Hoogeveen J, Döll P, Portmann FT (2010) Groundwater use for irrigation: a global inventory. Hydrol Earth Syst Sci 14(10):1863-1880

Sood A, Smakhtin V (2015) Global hydrological models: a review. Hydrol Sci J 60(4):549-565

Stettler E, De Beer J, Blom M (1989) Crustal domains in the northern Kaapvaal Craton as defined by magnetic lineaments. Precambrian Res 45(4):263-276

Taylor RG, Todd MC, Kongola L, Maurice L, Nahozya E, Sanga H, MacDonald AM (2013) Evidence of the dependence of groundwater resources on extreme rainfall in East Africa. Nat Clim Chang 3(4): 374-378

Tooth S, McCarthy T, Hancox P, Brandt D, Buckley K, Nortje E, McQuade S (2002) The geomorphology of the Nyl River and floodplain in the semi-arid Northern Province, South Africa. S Afr Geogr J 84(2):226-237

Trabucco A, Zomer RJ (2018) Global aridity index and potential evapotranspiration (ET0) climate database v2. CGIAR Consortium for Spatial Information (CGIAR-CSI). https://cgiarcsi.community. Accessed July 2021
Trambauer P, Maskey S, Werner M, Pappenberger F, Van Beek L, Uhlenbrook S (2014) Identification and simulation of space-time variability of past hydrological drought events in the Limpopo River basin, southern Africa. Hydrol Earth Syst Sci 18(8):29252942

UN (2019) World population prospects 2019: highlights. United Nations Department for Economic and Social Affairs, Paris

Van Wyk E (2010) Estimation of episodic groundwater recharge in semiarid fractured hard rock aquifers. University of the Free State, Bloemfontein, South Africa

Vegter JR (2003) Hydrogeology of groundwater region 7: Polokwane/ Pietersburg plateau. WRC report no. TT 209/03, Water Research Commission, Pretoria, South Africa

Vicente-Serrano SM, López-Moreno JI, Beguería S, Lorenzo-Lacruz J, Azorin-Molina C, Morán-Tejeda E (2012) Accurate computation of a streamflow drought index. J Hydrol Eng 17(2):318-332

Wada Y, Bierkens MF (2014) Sustainability of global water use: past reconstruction and future projections. Environ Res Lett 9(10): 104003

Walker D, Jovanovic N, Bugan R, Abiye T, du Preez D, Parkin G, Gowing J (2018) Alluvial aquifer characterisation and resource assessment of the Molototsi sand river, Limpopo, South Africa. J Hydrol 19:177-192

Ward JH Jr (1963) Hierarchical grouping to optimize an objective function. J Am Stat Assoc 58(301):236-244

Webster R, Oliver MA (1990) Statistical methods in soil and land resource survey. Oxford University Press, Oxford, UK

Wendt DE, Van Loon AF, Bloomfield JP, Hannah DM (2020) Asymmetric impact of groundwater use on groundwater droughts. Hydrol Earth Syst Sci 24(10):4853-4868

Wetterhall F, Winsemius H, Dutra E, Werner M, Pappenberger E (2015) Seasonal predictions of agro-meteorological drought indicators for the Limpopo basin. Hydrol Earth Syst Sci 19(6):2577-2586

Wright EP (1992) The hydrogeology of crystalline basement aquifers in Africa. Geol Soc Lond Spec Publ 66(1):1-27

Publisher's note Springer Nature remains neutral with regard to jurisdictional claims in published maps and institutional affiliations. 